\title{
KNOWING IS NOT ENOUGH: MIGRANT WORKERS' SPOUSES VULNERABILITY TO HIV
}

\author{
Aryal $\mathbf{N}^{1}$, Regmi PR ${ }^{2}$, Teijlingen E v ${ }^{3}$, Dhungel $\mathrm{D}^{4}$, Ghale $\mathrm{G}^{5}$, Bhatta $\mathrm{GK}^{6}$ \\ 1 PhD Student, Department of Medicine, University of Otago, Wellington, New Zealand \\ 2 Research Fellow, Faculty of Health and Social Sciences, Bournemouth University, Bournemouth, UK \\ Visiting Research Fellow, Chitwan Medical College, Tribhuvan University, Nepal \\ 3 Professor, Faculty of Health \& Social Sciences, Bournemouth University, Bournemouth, UK; \\ Manmohan Memorial Institute of Health Sciences, Tribhuvan University, Nepal; Nobel College, Pokhara University, \\ Nepal \\ 4 Country Program Manager, AIDS Healthcare Foundation (AHF) Nepal, Kathmandu, Nepal \\ 5 Section of Population Health, University of Aberdeen, Aberdeen, Scotland, UK \\ 6 SAARC Tuberculosis and HIVIAIDS Center, Thimi, Bhaktapur, Nepal
}

\begin{abstract}
Introduction: Male migrants and their sexual partners at home are at increased risk of STIs (Sexually Transmitted Infections) including HIV (Human Immunodeficiency Virus). We aimed to assess the knowledge and attitudes of migrants' wives regarding HIV and STIs, and to understand risk perception of HIV due to their husbands' sexual behaviour.

Methodology: A cross-sectional survey among 182 migrants' wives was conducted in two rural villages of Chitwan district in Nepal. The participants were selected through multistage cluster sampling method and data were collected through a questionnaire administered through a face-to-face interview.

Results: Nearly all (94\%) of migrants' wives had a good knowledge of HIV, however with some misconceptions. More than two-thirds of the participating migrants' wives were aware about the risk of HIV infection in migrant husbands and subsequent risk of transmitting themselves through sexual intercourse. Nearly half of the participants reported inability to ask their husbands about HIV and STIs even if they had their doubts. Knowledge of HIV and HIV risk associated with migration were statistically significantly higher in younger women, those who were literate and the longer the period of their husbands' migration.
\end{abstract}

Conclusion: Despite having generally a good knowledge and awareness of HIV and migration induced HIV risk; migrants' wives could not discuss sexual health issues with their husbands, thus increasing their vulnerability to HIV and STIs.

Key words: Culture, Sexual Health, Migration, Gender, South Asia.

\section{INTRODUCTION}

HIV prevalence is higher among migrants compared to non-migrants. ${ }^{1-3}$ In many countries, migrants account for larger proportion of total HIV infection.

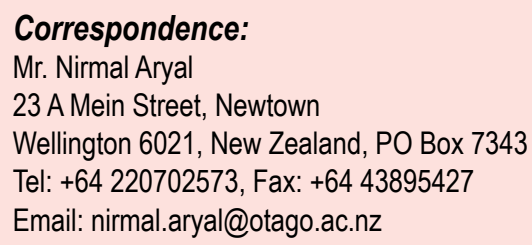

For example, in Europe, $49 \%$ of the heterosexually acquired HIV infection in 2009 was transmitted abroad. ${ }^{4}$ Studies in Africa and Asia demonstrated that female partners of male migrants are also at higher risk of HIV infection. ${ }^{5-7}$

As of July 2015, 26,702 cases of HIV were reported in Nepal. ${ }^{8}$ The total number of HIV infection was estimated to be 39,249 and adult HIV prevalence was $0.2 \% .^{9}$ Migrants working in India and their wives are recognized as most-at-risk populations for HIV in national strategies. ${ }^{10,11}$ The trend of seasonal and long-term male labour migration to 
India is common, particularly in the hilly districts of west and far-west region. ${ }^{12}$ Between 1.5 to 2 million Nepalese have migrated to India for short-term and long-term work. ${ }^{13}$ Resulting is a HIV prevalence of $0.8 \%$ among wives of migrants in far- western districts. ${ }^{14}$ Earlier in 2008, HIV prevalence of $3.3 \%$ was recorded among migrants' wives in west and far-west regions of the country. ${ }^{15}$ Against this backdrop, we focuses on two issues:(i) to assess knowledge and attitude of migrants' wives on HIV and STIs; and (ii) to understand knowledge of migrants' wives regarding their husbands risky sexual behaviours and their consequences.

\section{METHODOLOGY}

We conducted a cross-sectional survey ${ }^{16}$ in two villages of Chitwan district. We used multi-stage cluster samplings; first we randomly selected two villages to meet the target sample size of 180 which was determined considering time and resources. A sampling frame of the migrants' wives was developed. At the second sampling stage, we targeted at least 10 migrants' wives from each of the nine wards of each village. Our inclusion criteria included wives of male migrants of India, of reproductive age (15-45 years) and migration period being at least three months before the study. Inclusion criteria were assessed through self-reported response of the participants. The Nepal Health Research Council (NHRC) awarded research ethical approval.

Data were collected using a structured questionnaire, administered by an interviewer in Spring 2008. The questionnaire included sociodemographic characteristics and questions on awareness and knowledge of STls (such as syphilis, gonorrhoea, chlamydia) and HIV, and its symptoms. Four local female interviewers were selected as gender can have a significant influence on the responses, particularly in sensitive issues such as sex and HIV. ${ }^{17,18}$ Each questionnaire took 30-40 min. Face validity of the questionnaire was ensured with the consultation of relevant experts, whereas reliability was tested by conducting pilot study among 12 non-sampled migrant wives. All interviews were conducted in private location to maintain confidentiality. Data were analysed by Statistical Package for the Social Sciences (SPSS) version 15.0. The associations between sociodemographic variables and selected variables related to knowledge, attitude and risk perception on HIV were examined using Chi-squared tests, at a significance level of $p<0.05$.

\section{RESULTS}

In total, 182 wives of migrants participated. Of these, proportion in the youngest age group (1524 years) was higher $(n=54(30 \%))$, nearly half of them $(n=84(46 \%))$ had completed secondary school and two-thirds ( $\mathrm{n}=122(67 \%))$ were involved in household and agriculture related work. North India was the prime work destination ( $\mathrm{n}=91(50 \%))$ and more than one-third $(n=69(38 \%))$ served in the Indian army. Migration duration was more than 18 months for majority (82\%), while two-thirds usually came home at least once in a year time.

Overall, participants showed good knowledge of HIV and STIs, but with some misconceptions (Table 1). Likewise, participants displayed modest knowledge of STls signs and symptoms. Genital sore was commonly known STls symptoms as reported by nearly three-quarters $(n=135(74 \%))$, whereas lower abdomen pain was known to least number of the participants $(n=101(55 \%))$. Similarly, majority of the participants knew that HIV infection can be transmitted through sexual intercourse, if sex partners are multiple, through injecting drug use and from infected mother to new born child.

Table 1 indicates that slightly more than one-fifth of the participants believed 'HIV infection is the curse of God or sin of former life'. Similarly, nearly half of all participants stated that 'wives cannot ask even if there is a doubt of HIV or STIs on husbands'. Interestingly, just one-quarter of the participants knew about the existence of gay or lesbian relationships.

Many participants had misconceptions about HIV transmission (table 1). A significant proportion of the participants reported that HIV can be transmitted by mosquito/fly bites, by kissing, and by sharing same toilet and clothes. In contrast, participants were found to have good risk perception regarding migration related HIV and STIs. More than twothirds knew migrant men usually engaged in unprotected sex while staying abroad. Similarly, more than two-thirds perceived that spouses of migrants are vulnerable to HIV in Nepal and believed migrant men are at higher risk of HIV than non-migrant counterparts.

Table 2 shows that younger women (15-29 years) had better knowledge of HIV compared to those over 
30 , and this difference was statistically significant $(p=0.007)$. Likewise, difference was observed to be strongly significant between literate and illiterate participants $(p<0.000)$, literate ones being more knowledgeable. Similarly, knowledge on HIV

Table 1. Knowledge, attitude and risk perception of participants on HIV and STIs

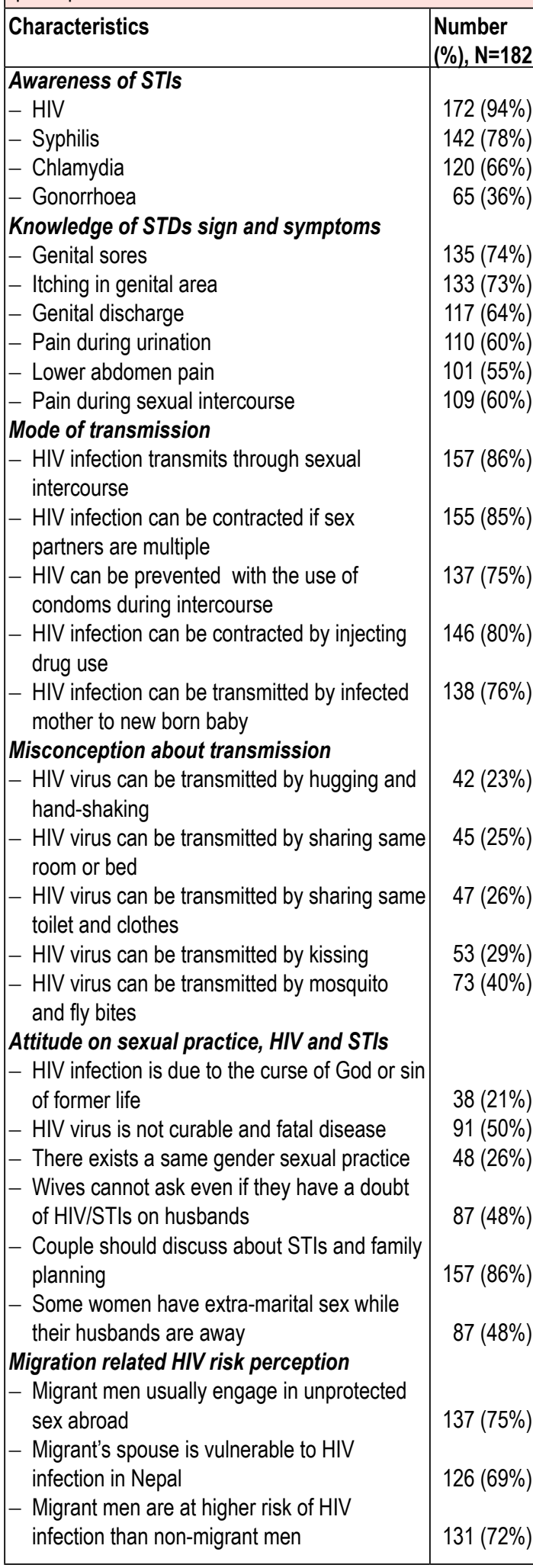

was significantly higher among those participants whose husbands usually returned home in more than one year than in those whose husbands came back in less than one year $(p=0.015)$. Knowledge of HIV was not found to be significantly associated with occupation and ethnicity.

Table 2. Association between levels of HIV knowledge and key socio-demographic variables

\begin{tabular}{|c|c|c|c|c|c|}
\hline \multirow[t]{2}{*}{ Variables } & \multicolumn{4}{|c|}{ Knowledge of HIV } & \multirow{2}{*}{$\begin{array}{c}P \\
\text { value }\end{array}$} \\
\hline & Good & Some & Poor & None & \\
\hline Age (yrs) & & & & & $0.007^{\star}$ \\
\hline $\begin{array}{l}-15-29 \\
-30-45\end{array}$ & $\begin{array}{r}63 \\
(65 \%) \\
54 \\
(64 \%)\end{array}$ & $\begin{array}{r}23 \\
(23 \%) \\
14 \\
(17 \%)\end{array}$ & $\begin{array}{r}6 \\
(6 \%) \\
7 \\
(8 \%)\end{array}$ & $\begin{array}{r}6 \\
(6 \%) \\
9 \\
(11 \%)\end{array}$ & \\
\hline Education & & & & & $<0.000^{* *}$ \\
\hline - Illiterate & $\begin{array}{r}7 \\
(23 \%)\end{array}$ & $\begin{array}{r}7 \\
(23 \%)\end{array}$ & $\begin{array}{r}5 \\
(17 \%)\end{array}$ & $\begin{array}{r}11 \\
(37 \%)\end{array}$ & \\
\hline - Literate & $\begin{array}{r}110 \\
(72 \%)\end{array}$ & $\begin{array}{r}30 \\
(20 \%)\end{array}$ & $\begin{array}{r}8 \\
(5 \%)\end{array}$ & $\begin{array}{r}4 \\
(3 \%)\end{array}$ & 0.750 \\
\hline Occupation & & & & & \\
\hline - Housework & $\begin{array}{r}26 \\
(72 \%)\end{array}$ & $\begin{array}{r}5 \\
(14 \%)\end{array}$ & $\begin{array}{r}1 \\
(3 \%)\end{array}$ & $\begin{array}{r}4 \\
(11 \%)\end{array}$ & \\
\hline - Houseworkt & $\begin{array}{r}77 \\
(63 \%)\end{array}$ & $\begin{array}{r}25 \\
(20 \%)\end{array}$ & $\begin{array}{r}10 \\
(8 \%)\end{array}$ & $10(8 \%)$ & \\
\hline Agriculture & & & & 1 & \\
\hline - Labour & $\begin{array}{r}7 \\
(54 \%)\end{array}$ & $\begin{array}{r}3 \\
(23 \%)\end{array}$ & $\begin{array}{r}2 \\
(15 \%)\end{array}$ & $\begin{array}{r}(8 \%) \\
0\end{array}$ & \\
\hline - Business/ Services & $\begin{array}{r}7 \\
(64 \%)\end{array}$ & $\begin{array}{r}4 \\
(36 \%)\end{array}$ & $\begin{array}{r}0 \\
(0 \%)\end{array}$ & $(0 \%)$ & \\
\hline $\begin{array}{l}\text { Caste / Ethnicity } \\
\text { - Janaiati }\end{array}$ & & 18 & 3 & & 0.587 \\
\hline tuajajail & $(66 \%)$ & $(20 \%)$ & $(3 \%)$ & $(10 \%)$ & \\
\hline - Brahmin /Chhetri & $\begin{array}{r}48 \\
(63 \%)\end{array}$ & $\begin{array}{r}17 \\
(22 \%)\end{array}$ & $\begin{array}{r}7 \\
(9 \%)\end{array}$ & $\begin{array}{r}4 \\
(5 \%)\end{array}$ & \\
\hline - Dalit & $\begin{array}{r}11 \\
(61 \%)\end{array}$ & $\begin{array}{r}2 \\
(11 \%)\end{array}$ & $\begin{array}{r}3 \\
(17 \%)\end{array}$ & $\begin{array}{r}2 \\
(11 \%)\end{array}$ & \\
\hline $\begin{array}{l}\text { Husband return } \\
\text { time }\end{array}$ & & & & & $0.015^{\star}$ \\
\hline$-<1$ year & $\begin{array}{r}71 \\
(59 \%)\end{array}$ & $\begin{array}{r}28 \\
(23 \%)\end{array}$ & $\begin{array}{r}8 \\
(7 \%)\end{array}$ & $\begin{array}{r}14 \\
(11 \%)\end{array}$ & \\
\hline$-1-2$ years & $\begin{array}{r}32 \\
(76 \%)\end{array}$ & $\begin{array}{r}4 \\
(10 \%)\end{array}$ & $\begin{array}{r}5 \\
(12 \%)\end{array}$ & $\begin{array}{r}1 \\
(2 \%)\end{array}$ & \\
\hline - >3 years & $\begin{array}{r}14 \\
(74 \%)\end{array}$ & $\begin{array}{r}5 \\
(26 \%)\end{array}$ & $\begin{array}{r}0 \\
(0 \%)\end{array}$ & $\begin{array}{r}0 \\
(0 \%)\end{array}$ & \\
\hline
\end{tabular}

${ }^{*} p$ value significant at 0.5 level, ${ }^{* *} p$ value significant at 0.01 level

Younger age (15-29 years), being literate and long gap in husband's returning time was significantly associated with the perceived risk 'migrant's wives are vulnerable to HIV in Nepal' (Table 3). Occupation and ethnicity did not have significant impact upon this risk perception.

The greater proportion of the literate participants perceived that 'migrant men usually engage in unprotected sex abroad' as compared to illiterate participants $(80 \%$ vs. $50 \%)$, and this difference 


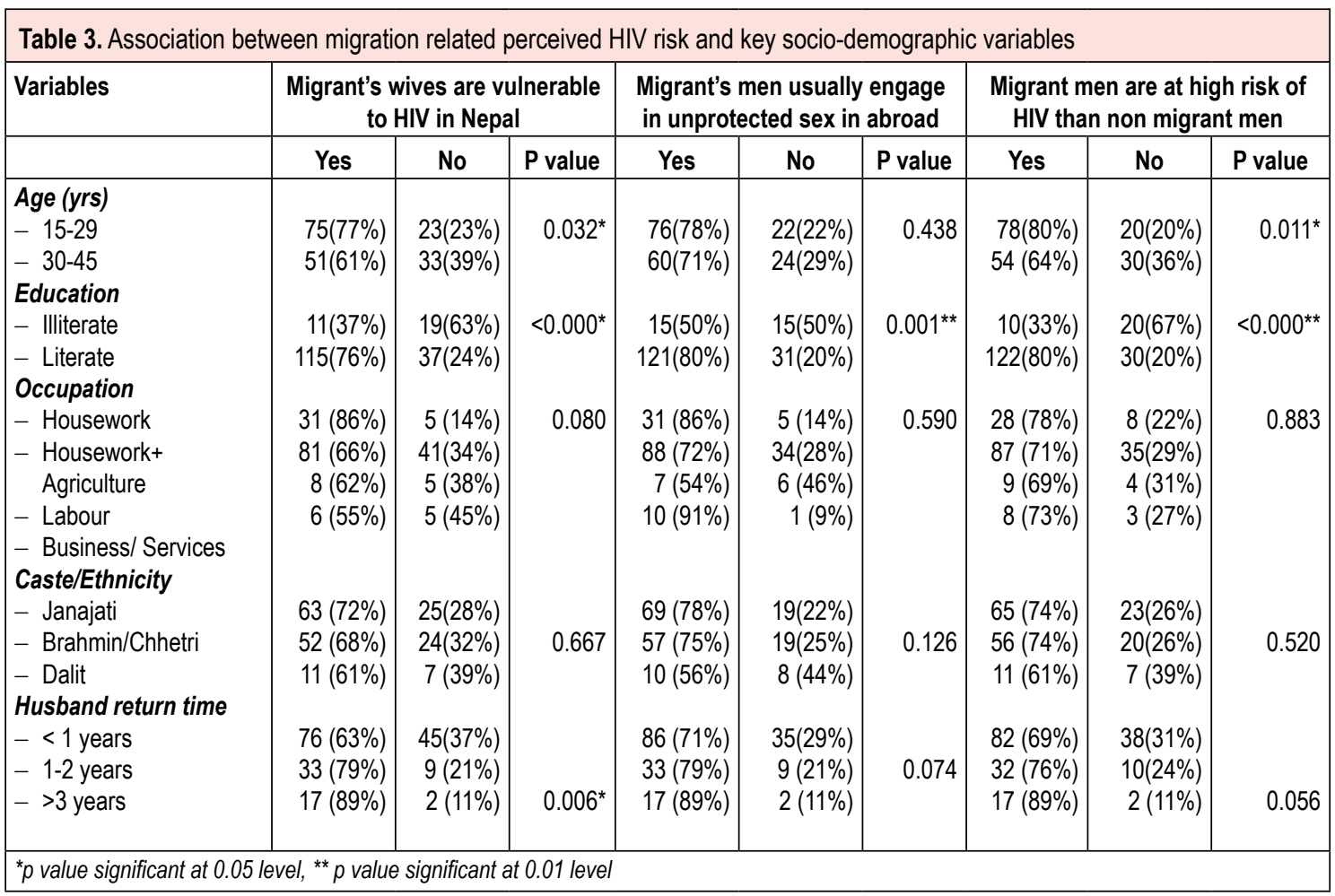

was statistically significant $(p=0.001)$ (table 3$)$. The trend was clearly observed that participants were more likely to perceive this risk accordingly with the increasing gap in returning time of their husbands, but the difference was statistically insignificant $(p=0.074)$.

Literate participants were more likely to perceive that migrant men are at high risk of HIV than nonmigrant men (table 3). The difference in proportions between literate and illiterate participants was statistically strongly significant $(80 \%$ vs. $33 \%$, $p<0.0001$ ). Similarly, participants with younger age group (15-29 years) were significantly more likely to perceive this risk as compared to the participants of older age group (30-45 years) ( $80 \%$ vs. $64 \%$, $p=0.011)$. Occupation and ethnicity did not have any impact for this risk perception. However, participants whose husband's returning time was long were more likely to perceive this risk, $p=0.06$.

\section{DISCUSSION}

Our study shows that the vast majority of the migrants' wives had overall good knowledge of HIV, albeit, with some misconceptions on mode of transmission. Furthermore, we demonstrated that more than two-thirds of the participating migrants' wives were aware about the migration induced
HIV risk. Despite this situation, nearly half of them reported that they couldn't ask about husbands' infidelity and risk of STIs and HIV infection even though they had a doubt.

Our findings on knowledge of HIV and prevention method was fairly similar to the result of Integrated biological and behavioural surveillance (IBBS) survey 2010 conducted among 600 wives of migrants in four districts of far-western Nepal. In this survey, $96.3 \%$ of participating migrants' wives stated having heard of HIV, $97.5 \%$ were aware about condoms but $60.9 \%$ of them never used it, and majority of the participants knew the key prevention methods of HIV infection. ${ }^{14}$ Likewise, Nepal demographic and health survey (NDHS) 2011 suggested that $86 \%$ of Nepalese women were aware of HIV and $79 \%$ of the women knew that HIV infection can be prevented by limiting sex to one partner who has no other sexual partner. ${ }^{19}$ The high level of knowledge on HIV may be hugely attributed to increasing access of electronic media (especially F.M. radio) in Nepalese communities.

This study noted that $23 \%$ to $40 \%$ of participating migrants' wives had incorrectly answered the questions related to mode of transmission of HIV. A small study among 150 Nepalese adolescents concluded that the vast majority of the participants 
had misconceptions on mode of transmission such as HIV can be transmitted by holding hands, kissing, through air alike cold diseases, mosquito bite etc. ${ }^{20}$ Another study among returnee male migrants in far-western Nepal also showed that majority knew the main routes of HIV transmission, but still had misconceptions about other routes. ${ }^{21}$

We found that knowledge of HIV and migration related perceived risk of HIV is significantly associated with younger age, being literate and longer period of husbands' migration. Our findings are corroborated by several other studies conducted in Nepal. For example, a study on rural married women from migrant community in Kailali district documented that $75 \%$ of women with some formal education had heard of HIV and STIs as compared to $34 \%$ of those with no formal education.22 Regarding an association with education, NDHS suggested that younger Nepalese women were more likely to have knowledge about HIV and its prevention measures. ${ }^{19}$ An association between HIV knowledge and longer migration period of husbands may be because longer stay increases the likelihood of indulging in extra-marital $\operatorname{sex}^{23}$ and being aware of this situation migrants' wives might become interested to gain knowledge on HIV.

The most important finding is that two-thirds of the participating migrants' wives knew migration induced risk of STIs and HIV, yet $48 \%$ of them thought that they should not ask husbands about this. This clearly pointing to a gap between 'knowing and acting' a phenomenon also noted among wives of Tajik migrants. ${ }^{24}$ and wives of male Mexican migrants to the United States of America. ${ }^{25}$

The main reason which inhibits migrants' wives of Nepalfromnegotiating on safer sexis historically and culturally entrenched gender-based discrimination in every domain of life. Nepalese women have limited access to education, employment, health, decision making and thus they were dependent on husband even for sexual direction. Economic dependency is the major factor which prevents wives to discuss on sexuality, HIV related diseases and HIV prevention ${ }^{26}$ which is largely true among migrants' wives in our study. The role of 'power' in sexual relationship was demonstrated in a study on South Asian migrant women in Canada where women with high power in relationship had a high level of knowledge on HIV and they could ask their partner to use a condom. ${ }^{27}$ Furthermore, in Nepalese context, migrants often gain new social status after returning to home, ${ }^{21}$ which may have influences on their sexual dominance over sexual partners. On the other hand, the issue of sexuality is still a taboo in Nepalese society. Nepalese women who initiate discussion about sexuality and issues such as use of condom are apparent to be unfaithful or characterless. ${ }^{28}$

There are several limitations of this study. First, the sample of this study was not a national sample, but from one district. Secondly, more than one-third of the participants fell on one category of migrant wives of Indian army and wives of Nepali migrants going to Middle East and Asia Pacific regions were not included. We could not rule out the possibility that this group of participants were significantly different from other groups in many ways such as higher financial position and increased access to health services and mass media (television, radio). Finally, we could not compare wives of migrants with wives of non-migrants which may be important to notice if migrants' wives have different levels of knowledge, attitude and perception on HIV with associated implications in terms of risk of having HIV.

Our study suggests intensifying the programmes which helps to build conducive environment and encourage migrants' wives to communicate on HIV and STIs risk with their partners and cooperation and support from male migrants is critical. Next, the power of mass media should be fully utilized to dispel the prevalent misconceptions on HIV and STIs. Health care workers at grass-root level should also be adequately sensitized and mobilized for this purpose. Further, most of the HIV related programs are being focused on safer sex practice, but we firmly urge to give attention towards the 'contextual barriers' such as discriminatory cultural practices, uneven power relations in sexual relationships, dearth of awareness on sexual roles and rights of women etc. Finally, a nationally representative study would be important to better understand the knowledge, attitude and perception of HIV among migrants' wives and concomitant sexual health risk. Future research should also include wives of Nepali migrants irrespective of their age and husband's destinations. 


\section{Acknowledgements}

We like to thank all participants for their contribution. We are also grateful to Mr. Nabin Chhetri (University of Oxford) for useful suggestions on language and grammar.

\section{REFERENCES}

1. Gupta K, Singh SK. Social networking, knowledge of HIV/Aids and risk-taking behaviour among migrant workers. International Union for the Scientific Study of Population (IUSSP) Regional Population Conference on Southeast Asia's Population in a Changing Asian Context. Bangkok: Thailand [Internet]; 2002. Available from http:// www.iussp.org/Bangkok2002/S06Gupta.pdf.

2. Lagarde E, van der Schim LM, Enel C, Holmgren $B$, Dray-Spira R, Pison $G$, et al. for the MECORA group. Mobility and the spread of human immunodeficiency virus into rural areas of West Africa. Int J Epidemiol. 2003;32:744-752

3. George S, Jacob M, John TJ, Jain MK, Nathan N, Rao P.S.S., et al. A case-control analysis of risk factors in HIV transmission in South India. J Acquir Immune Defic Syndr. 1997;14:290-293.

4. European Centre for Disease Prevention and Control and WHO Regional Office for Europe. HIVI AIDS surveillance in Europe 2009. Stockholm: European Centre for Disease Prevention and Control; 2010.

5. Halli SS, Blanchard J, Satihal DG, Moses S. Migration and HIV transmission in rural South India: an ethnographic study. Culture, Health \& Sexuality. 2007:9:85-94.

6. Qin $\mathrm{Q}-\mathrm{R}$, Ji GP, $\mathrm{Xu}$ J, Jiang $\mathrm{Q}-\mathrm{C}$, Hong $\mathrm{H}$, Chu $X-Y$, et al. Risk of sexual HIV transmission among wives left behind and wives of nonmigrant men in rural areas of China. Journal of the Association of Nurses in AIDS Care. 2009; 20(4):308-315.

7. Lurie M, Williams B, Zuma K, Mkaya-Mwamburi D, Garnett G, Sweat, MD, et al. Who infects whom? HIV concordance and discordance among migrant and non-migrant couples in South Africa. AIDS. 2003;17:2245-52.

8. NCASC 2015 HIV situation in Nepal (revised and updated on 30/11/2015) http://www.ncasc.gov.np/ index.php

9. National Centre for AIDS and STD Control (NCASC). Factsheet no. 1: HIV epidemic update of Nepal, December 2013. Kathmandu: Ministry of Health and Population; 2014.
10. NCASC 2011 National HIV/AIDS Strategy 2011-16. Kathmandu: Ministry of Health and Population

11. NCASC (2013). Nepal Investment Plan (2014-16). Kathmandu: Ministry of Health and Population.

12. Bhurtyal $Y$, Joshi $S$. Health and Social Issues of Migrants and Left Behind Families. In: Wasti, S., Simkhada, P. and Van Teijlingen, E., eds. The Dynamics of Health in Nepal. Kathmandu: Social Science Baha, 2015; 201-221.

13. Vaidya NK, Wu J. HIV epidemic in Far-Western Nepal : effect of seasonal labor migration to India. BMC Public Health. 2011;11:310.

14. New Era, Intrepid Nepal, and FHI Nepal. Integrated biological and behavioural surveillance (IBBS) survey among wives of migrants in four districts of far-western Nepal (round II-2010). Kathmandu: New Era; 2010.

15. Joint United Nations Program on HIVIAIDS (UNAIDS). UNGASS country progress report Nepal 2008. Kathmandu: Ministry of Health and Population; 2008.

16. Bowling A. Research methods in health: investigating health and health services.(3rd ed.) Maidenhead: Open University Press; 2009.

17. Axinn WG. The influence of interviewer sex on responses to sensitive questions in Nepal. Soc Sci Res. 1991;20:303-18.

18. Ingham R, Vanwesenbeeck I, Kirkland D. Handbook of the psychology of interviewing. Memon, A, Bull, R (eds). Chichester: John Wiley and Sons; 1999.

19. Ministry of Health and Population. Nepal demographic and health survey 2011: preliminary report [Internet]; 2011. Available from http://www. measuredhs.com/pubs/pdf/PR11/PR11.pdf.

20. Mahat G, Scoloveno MA. HIV/AIDS knowledge, attitudes and beliefs among Nepalese adolescents. J Adv Nurs. 2006;53(5):583-590.

21. Poudel KC, Jimba M, Okumara J, Joshi AB, Wakai $S$. Migrants' risky sexual behaviours in India and at home in far western Nepal. Trop Med Int Health. 2004;9(8):897-903.

22. Smith-Estelle A, Gruskin S.Vulnerability to HIV/STIs among rural women from migrant communities in Nepal: A health and human rights framework. Reprod Health Matters. 2003;11(22):142-151.

23. Poudel KC, Okumara J, Sherchand JB, Jimba $M$, Murakamai I, Wakai S. Mumbai disease in far western Nepal: HIV infection and syphilis among 
male migrant-returnees and non-migrants. Trop Med Int Health. 2003;8(10):933-939.

24. Golobof A, Weine S, Bahromov M, Luo J. The role of labor migrants' wives in HIVIAIDS risk and prevention in Tajikistan. AIDS Care. 2011;23(1):9197.

25. Salgado de Snyder VN, Diaz PM, Maldonado M. AIDS: risk behaviours among rural Mexican women married to migrant workers in the United States. AIDS Educ Prev. 1996;8(2):134-142.
26. Hong H, Qin QR, Li LH., Ji GP, Ye D-Q. Condom use among married women at risk for sexually transmitted infections and HIV in rural China. Int J Gynecol Obstet. 2009;106(3):262-265.

27. Gagnon AJ, Merry L, Bocking J, Rosenberg E, Oxman-Martinez J. South Asian migrant women and HIV/STIs : Knowledge, attitudes and practices and the role of sexual power. Health Place. 2010;16(1):10-15.

28. Poudel P, Carryer J. Girl-trafficking, HIVIAIDS, and the position of women in Nepal. Gender Dev. 2000;8(2): 74-79. 